University of Nebraska - Lincoln DigitalCommons@University of Nebraska - Lincoln

USGS Staff -- Published Research

US Geological Survey

2015

\title{
Possible Tsunami Deposits on the Caribbean Coast of the Yucatán Peninsula
}

Charles Shaw

Centro Ecológico Akumal, Mexico, yucatanchas@hotmail.com

Larry Benson

U.S. Geological Survey, great.basin666@gmail.com

Follow this and additional works at: http:// digitalcommons.unl.edu/usgsstaffpub

Part of the Earth Sciences Commons, and the Oceanography and Atmospheric Sciences and Meteorology Commons

Shaw, Charles and Benson, Larry, "Possible Tsunami Deposits on the Caribbean Coast of the Yucatán Peninsula" (2015). USGS Staff -Published Research. 890.

http:// digitalcommons.unl.edu/usgsstaffpub/890

This Article is brought to you for free and open access by the US Geological Survey at DigitalCommons@University of Nebraska - Lincoln. It has been accepted for inclusion in USGS Staff -- Published Research by an authorized administrator of DigitalCommons@University of Nebraska - Lincoln. 


\title{
Possible Tsunami Deposits on the Caribbean Coast of the Yucatán Peninsula
}

\author{
Charles E. Shaw ${ }^{\dagger *}$ and Larry Benson ${ }^{\dagger * *}$ \\ ${ }^{\dagger}$ Centro Ecológico Akumal \\ Akumal 77776, Quintana Roo, México \\ ${ }^{\ddagger}$ Natural History Museum \\ University of Colorado \\ Boulder, Colorado 80309, U.S.A.
}

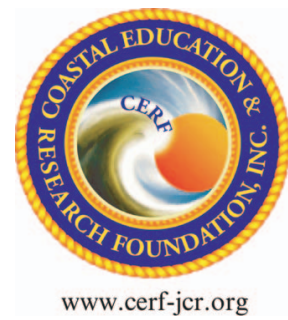

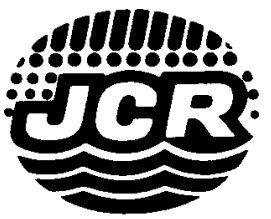

www.JCRonline.org

\begin{abstract}
Shaw, C.E. and Benson, L., 2015. Possible tsunami deposits on the Caribbean coast of the Yucatán peninsula. Journal of
\end{abstract} Coastal Research, 31(6), 1306-1316. Coconut Creek (Florida), ISSN 0749-0208.

\begin{abstract}
The western Caribbean Basin is notable for its tectonic stability. It has experienced no historical earthquakes or the tsunami that sometimes accompany them. This paper describes a single, wedge-shaped, boulder-covered, coastal berm on the Yucatán coast of México that stretches unbroken for $50 \mathrm{~km}$ across a coastal segment characterized by rocky headlands that alternate with crescent beaches. The remainder of the $350 \mathrm{~km}$ of Yucatán coast consists mostly of mangrove that extends 1 to $30 \mathrm{~km}$ inland, often behind long, sandy beaches. On the headlands, the surface of the berm is densely paved with boulders-large boulders on its seaward face and smaller boulders and cobbles on its gently sloping inland surface. The top of the berm reaches an elevation $>4 \mathrm{~m}$, above the reach of all but the largest modern storm waves. Berm sediments on the headlands consist of two distinct layers of unbedded coarse sand with numerous randomly distributed boulders and cobbles in the lower layer and a crudely textured gravel and sand layer above. At first glance the two layers appear to be separated by $20 \mathrm{~cm}$ of white sand above a thin, discontinuous zone of dark, greyish sand that contains isolated balls and smears of black organic material, apparently derived from a soil, or possibly leaf litter. The berm and its associated boulders track the modern coastal morphology in precise detail as it follows the form of modern headlands, bays, and transcoastal channels, indicating that deposition took place after development of the present coast. The berm sediments record two or three large waves, depending on whether the wave that deposited the boulder pavement is regarded as part of the second wave or as a separate wave. Radiocarbon dating indicates that at least one wave struck the coast approximately 1500 years before present. Minimum wave run-up exceeds $4 \mathrm{~m}$ above present sea level, and inland inundation reached $400 \mathrm{~m}$ along bays and transcoastal channels. The position and elevation of the berm, its lack of well-developed internal bedding, the paving of the berm surface by thousands of boulders, and its $400-\mathrm{m}$ extent inland along channels and bays are features commonly associated with tsunami. However, some recent studies conclude that all of the features listed also can be produced by mega-hurricanes. Placed in the context of our literature search of the recent history of hurricanes and tsunami in the Caribbean Basin, we conclude that the single berm on the Yucatán coast represents an anomalous event for this area and that the berm sediments bear a strong similarity to descriptions of sediments from some historical tsunami and are unlike sedimentary features associated with historical
\end{abstract} hurricanes.

ADDITIONAL INDEX WORDS: Holocene, beaches, mangrove, pumice, hurricane.

The western Caribbean Basin is rarely mentioned as a place that suffers either earthquakes or tsunami. However, numerous large, imbricated boulders up to $1 \times 0.75 \times 0.5 \mathrm{~m}$ are found paving the seaward face of an inland-tapering, wedge-shaped berm along a well-defined 50-km segment of the Caribbean coast between Tankah and Playa del Carmen on México's Yucatán Peninsula (Figure 1). These features suggest that at least one tsunami might have impacted the Yucatán coast.

The coast between Tankah and Playa del Carmen contains the highest topography on the shore and is uniquely characterized by alternating bays and rocky headlands. However, this area of high coast constitutes only a small part of the $375-\mathrm{km}$ long Caribbean coast that, with two small exceptions, consists of low-lying mangrove wetlands. Sediments that form the berm on the high coast are $2.5 \mathrm{~m}$ thick on the boulder-paved seaward

DOI: 10.2112/JCOASTRES-D-14-00084.1 received 5 May 2014; accepted in revision 16 December 2014; corrected proofs received 5 February 2015; published pre-print online 4 March 2015.

*Present address: 856 Parcel Street, Monterey, CA 93940, U.S.A.; yucatanchas@hotmail.com

**Present address: 602 Pine Street, Boulder, CO 80302, U.S.A.

${ }^{\circ}$ Coastal Education and Research Foundation, Inc. 2015 face (Figures 2 and 3) and thin inland. The inland surface of the berm also is densely paved, but with smaller boulders and cobbles that are spread inland over a distance of $70 \mathrm{~m}$ (Figure 4). The rocky platforms that form the headlands reach more than $2 \mathrm{~m}$ above sea level, which combined with the 2.5-m thickness of the berm places the top of the sediments at around $4.5 \mathrm{~m}$ above present sea level. The 4.5-m elevation of the berm, together with its 20-30-m distance from the shore, places it beyond the reach of most modern storm waves. The rock platform between the berm and the sea has a relief of $<0.5 \mathrm{~m}$ and is swept clean of sediment (Figure 2).

In the bays between headlands, the berm is composed of wellsorted beach sand mixed with varying amounts of boulders. At Half Moon Bay, the beach sand is mixed with massive accumulations of boulders for $300 \mathrm{~m}$ northward from the headland between it and Akumal Bay. The boulders are composed of modern coral from the offshore reef and finegrained limestone, presumably from beneath the bay floor. The largest boulders reach $0.5 \mathrm{~m}$ in length (Figure 5 ).

Despite their prominence and ease of access, no mention of the boulders at Akumal, or elsewhere along $50 \mathrm{~km}$ of headlanddominated coast, appears in the geological literature we have 


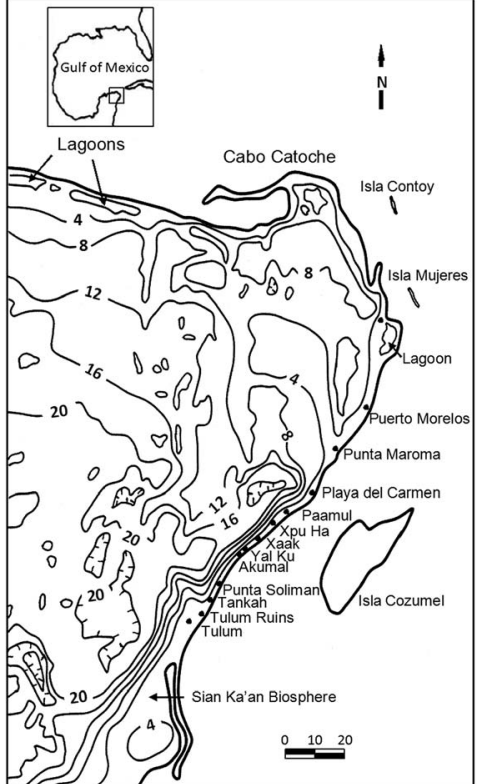

Figure 1. Location map of the northeastern Yucatán Peninsula and the northeastern Caribbean coast showing topography and localities mentioned in the text. Boulders pave a berm of gravel and sand that spans $50 \mathrm{~km}$ between Tankah and Playa del Carmen. Contour interval is $4 \mathrm{~m}$ and was constructed by interpolation from 1:50,000 topographic sheets with a $10-\mathrm{m}$ contour interval.

reviewed. This paper provides the first description of the berm and the deposits that form it, other than a brief mention by Shaw (1996) as part of a paper on coastal morphology delivered at the 1996 annual meeting of the Geological Society of America, which simply stated that a boulder-paved berm of possible tsunamigenic origin exists on the Caribbean coast of

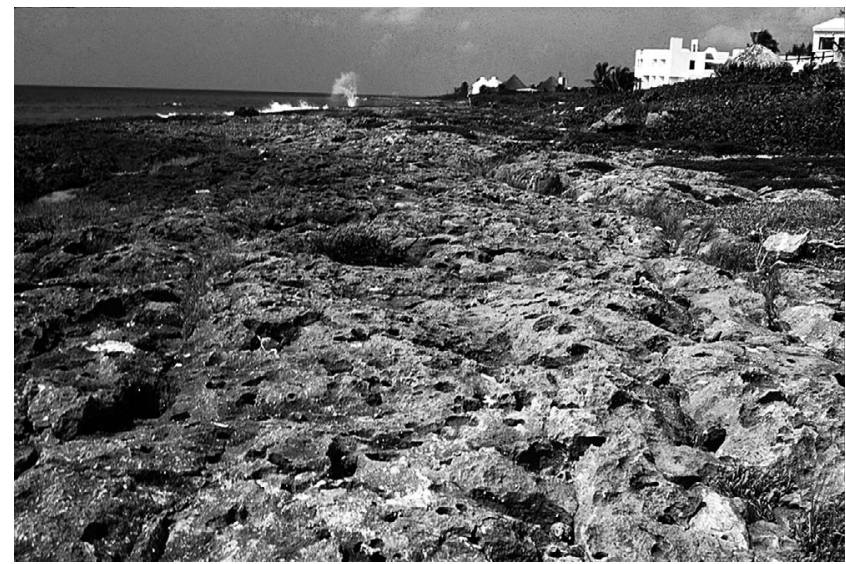

Figure 2. View south along the Akumal headland showing the relationship between berm and headland. Rock platform is underlain by Late Pleistocene reef rock. The boulder and sand berm underlies the vegetated area on the right, where boulders paving the seaward face poke through the vegetation. Blowhole is $400 \mathrm{~m}$ distant, near the locality of Figure 3.

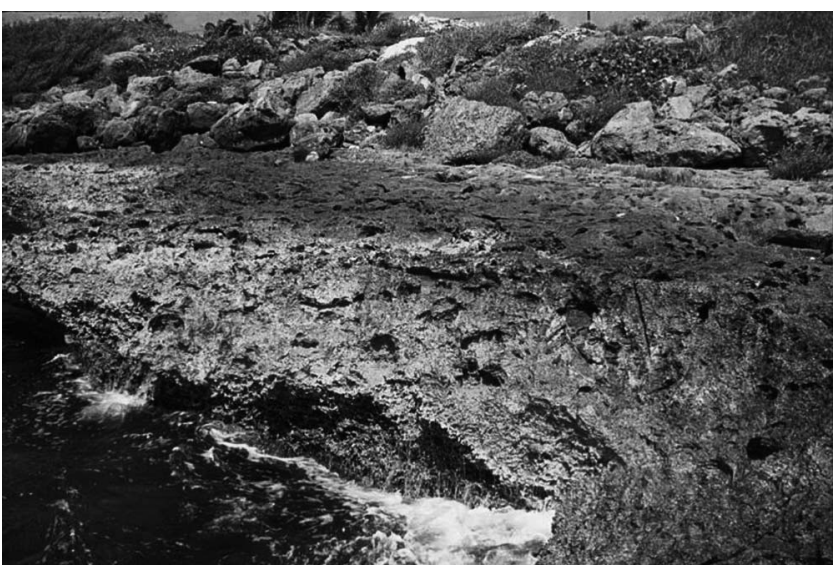

Figure 3. Boulders pave the seaward side of the berm at Mi Casa del Mar. Late Pleistocene reef rock of the Akumal headland in the foreground is the west side of a square indentation in the headland near A in Figure 6 Distance between water surface and top of headland rocks is about $1.5 \mathrm{~m}$. Tan color above the water marks the intertidal zone.

México. A more complete report on the origin and age of the modern Yucatán coast has been accepted for publication in the Journal of Coastal Research. In the present paper we describe the wedge-shaped body of boulders, gravel, and sand on the coastal headlands and adjacent bays, establish their Holocene age, and discuss their possible origins.

\section{METHODS}

A systematic survey of the coastline between Cancun and the Belize border with México was carried out by the senior author over 2 years beginning in the early 1990 s on what was then a mostly uninhabited coast. This survey was mainly to learn about groundwater discharge to the ocean, but at the same

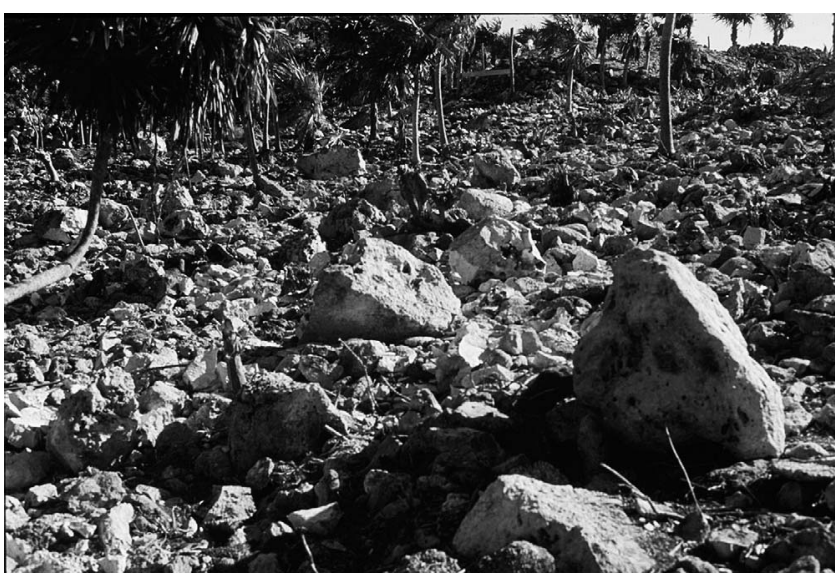

Figure 4. Boulders paving the landward side of the berm at Mi Casa del Mar, Akumal (A on Figure 6). View to the east (seaward) shows dense boulder cover and angular shapes of larger clasts. Smaller cobbles between larger clasts are rounded. Berm crest overlooks the Caribbean at top right, about $50 \mathrm{~m}$ distant. 


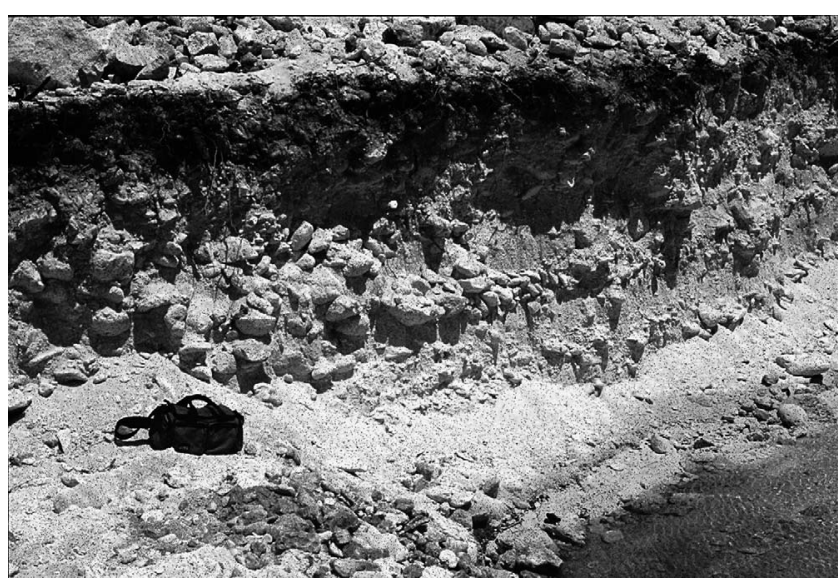

Figure 5. Subrounded boulders and cobbles mixed with sand at Half Moon Bay. Boulders and cobbles are composed of coral from the modern reef and blocks of fine-grained, Late Pleistocene limestone. Camera bag on ground is $16 \mathrm{~cm}$ high. Photograph shows about $3 \mathrm{~m}$ of a 50-m-long excavation.

time, the geographical extent of the berm and boulders first recognized at Akumal was established, and variations in boulder density and their locations and dimensions were documented. Maya buildings found on the berm crest near Playa del Carmen constrain the berm's age as before the postclassic period of Maya history (Sabloff, 1989). However, excavations that would allow study of sediments composing the berm were essentially nonexistent until the tourism boom of the late 1990s, and even then accessibility was limited by the developers. Descriptions of berm sediments in this paper, therefore, are based on a single large excavation on the headland berm at Akumal, one small excavation on the headland berm near the Yal $\mathrm{Ku}$ channel, and several excavations in the beach berm at Half Moon Bay. Localities are indicated by capital letters on Figure 6.

The single large excavation was opened at Akumal for a brief period in February 1998. Its purpose was to build footings for construction of Mi Casa del Mar Condominiums (A on Figure 6 ). Because the excavation trenches were open for only a very short time, the strategy adopted was to photograph the excavation and collect samples for later reference. Descriptions are based on the photographs, notes, and a limited number of samples.

Thick vegetation covering the landward side of the berm was removed by workers using machetes, thus preserving undisturbed a previously unsuspected continuous pavement of boulders and cobbles on the inland surface of the berm (Figure 4). The grid of trenches shown in Figures 7A and 7B provides a three-dimensional view of the internal structure of the berm and provided data for construction of the cross section in Figure 8.

Excavations also were opened between headlands for construction projects at Half Moon Bay and elsewhere. At Half Moon Bay, excavation near the center of the beach for construction of the Playa Caribe Condominiums revealed mangrove peat below the beach sand, which is assumed to be continuous with peat found within the surf zone. Samples of

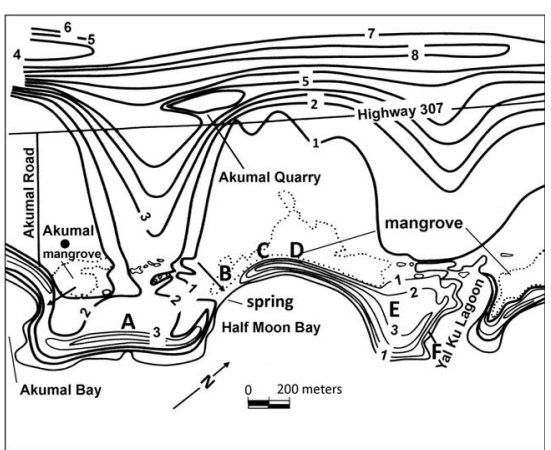

Figure 6. Topographic map of Half Moon Bay and Yal Ku Lagoon. The narrow coastal berm is set on a headland about $2 \mathrm{~m}$ above present sea level and tracks the coastline in detail, indicating deposition after development of the modern coast. At the Yal Ku channel, berm deposits can be traced inland for $400 \mathrm{~m}$ on both sides, dropping in elevation with distance. Other indentations in the coastline show similar inland extent of the berm. Arrows indicate probable return flow of seawater from the depositing wave(s) via channels that cross the beaches at Akumal Bay and Half Moon Bay. Letters on the map indicate specific localities discussed in the text: $\mathrm{A}=\mathrm{Mi}$ Casa del Mar, $\mathrm{B}=$ Playa Blanca Condominiums, $\mathrm{C}=$ Playa Caribe Condominiums, $\mathrm{D}=$ La Joya Condominiums, $\mathrm{E}=$ Cobbles on inland side of berm, $\mathrm{F}=$ house excavation on the Yal Ku channel.

peat for radiocarbon dating were collected from the surf zone, and results were compared with the recent sea level curves of Milliken, Anderson, and Rodriguez, (2008) and of Toscano and Macintyre (2003) and with records of modern earthquakes, tsunami, and hurricanes in the Caribbean Basin.

A literature search for boulder and berm deposits in the Caribbean basin and nearby areas revealed cases of isolated single boulders or groups of boulders in the Bahamas (Hearty, 1997), from within the Caribbean Basin at Grand Cayman Island (Jones and Hunter (1992), and from Isla de Mona west of Puerto Rico and Hispaniola (Taggart et al., 1993). Scheffers (2002, 2004) and Scheffers and Kelletat (2006) document multiple boulder ridges in the Lesser Antilles, which they interpret as resulting from tsunami. Chevron ridges were reported from Eleuthera Island in the Bahamas (Hearty, 1997), which, like boulders near them, were interpreted as the products of extreme wave events.

\section{RESULTS}

The reconnaissance survey of the coast carried out in the early 1990s showed that a sand and gravel berm paved with large boulders and reaching more than $4 \mathrm{~m}$ above present sea level is a continuous feature across $50 \mathrm{~km}$ of rocky coastline between Playa del Carmen and Tankah (Figure 1). Figure 1 also shows that the rocky coast is developed along the edge of a prominent crustal block that protrudes eastward from the regional trend seen to the southwest. The block has an elevation of $20 \mathrm{~m}$ at $6 \mathrm{~km}$ west of Akumal. The base of the block is outlined by the $4-\mathrm{m}$ contour $1 \mathrm{~km}$ inland. West of Tulum, the 4-m contour is $8 \mathrm{~km}$ inland and, west of Cancun, is $35 \mathrm{~km}$ inland, with the exception of an isolated ridge $9 \mathrm{~km}$ inland near Cancun. This block presents a very different morphology to incoming waves than that of the wide, low-lying 


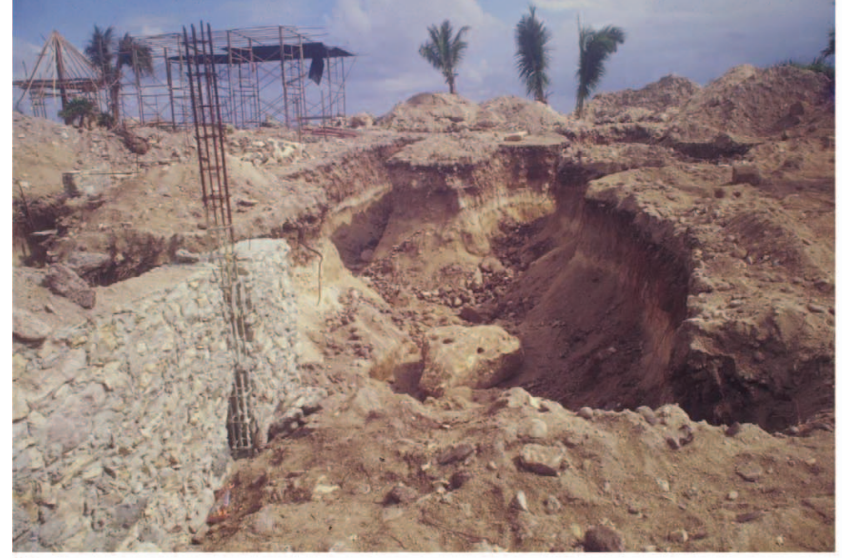

A

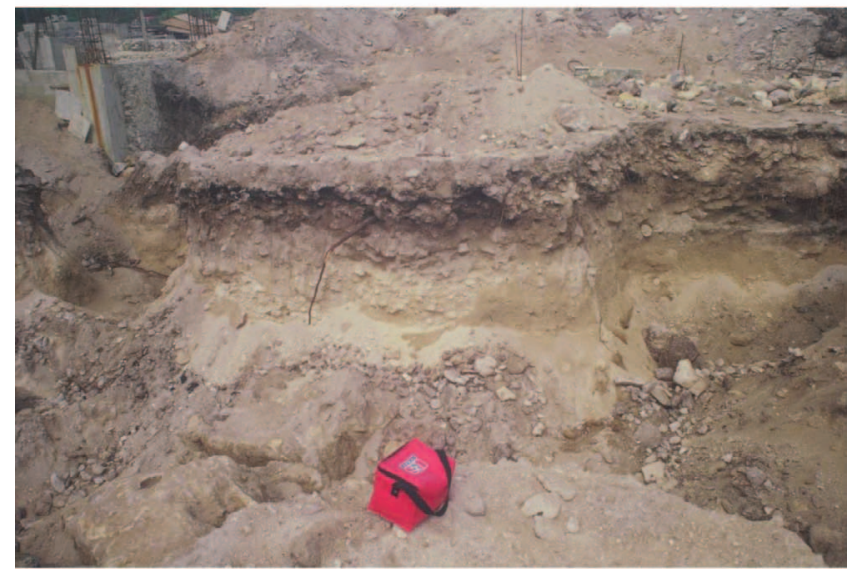

B

Figure 7. Photographs of excavation at Mi Casa del Mar showing continuity and character of sediment layers. (A) Overview of trenches. Wave flowed toward the observer. The land surface above the modern soil is composed of spoil from the excavation. Note large boulders in nearby spoil piles. Stone and cement wall in foreground is $1 \mathrm{~m}$ high. Two thick sand and gravel units are separated by a 20 - to $30-\mathrm{cm}$-thick white sand that can be followed around the trench walls. (B) Detail in trench wall directly in front of where the constructed stone wall in panel A ends. Photograph was taken from the top of the wall opposite. The same root emanating from the base of the dark gravel is seen in both photographs. End of the stone wall in panel A appears in panel $\mathrm{B}$ at far left. Bag in foreground is $14 \mathrm{~cm}$ high. The trench wall is $1 \mathrm{~m}$ high. Upper unit above the white gravel is about $35 \mathrm{~cm}$ thick and is composed of poorly sorted, dark reddish-brown gravel. Clasts are subangular and tabular in shape. The tabular clasts are crudely packed and oriented in attitudes that produce a rough fabric similar to that found in landslides. Spoil at the bottom of the trench reveals shapes and sizes of individual clasts. There is no discernable change in the size of clasts downslope. Close to the crest of the berm, the reddish gravel grades downward to white sand. Farther downslope, the white sand is replaced by the white gravel shown in panel B. The white sand rests with sharp contact on top of dark brown sand containing numerous floating boulders. Sand fraction in both layers is subangular and coarse-grained and lacks fine sand, silt, or clay. In texture and degree of roundness, it resembles sand on the present sea floor.

mangroves to the north and south, where wave energy is dissipated across the wetlands. Waves striking the high coast near Akumal, on the other hand, encounter a topographic relief of more than $2 \mathrm{~m}$ at the headland shore, apparently resulting in

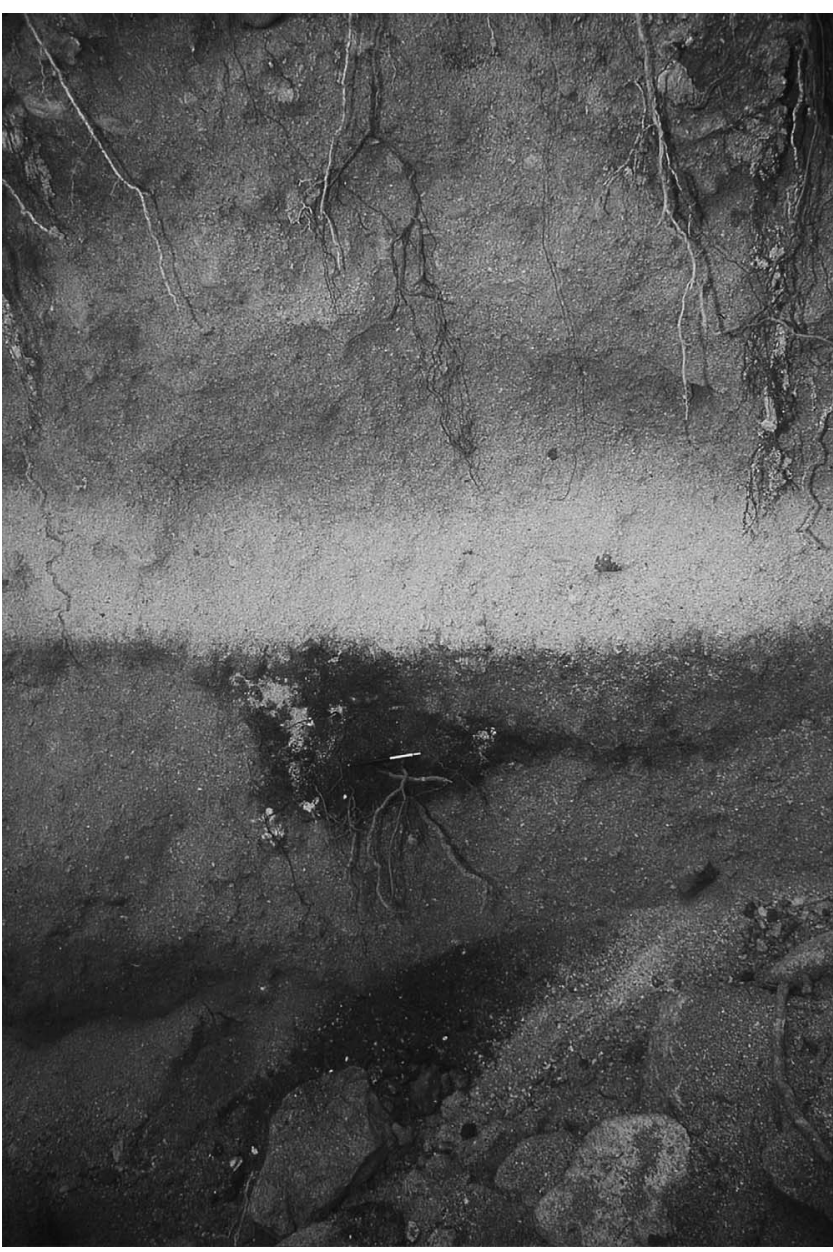

Figure 8. Photograph taken upslope from those in Figure 7 contains much less reddish gravel and boulders. The white sand, 20-30-cm thick, contains small, white pebbles plus a few larger coral fragments and rests with a sharp contact above the lower unit. Below the contact, a mass of organic material is preserved within a discontinuous zone of dark brown sand. Pen on the organic mass is $14 \mathrm{~cm}$ long. Close examination of texture indicates a gradational contact upward between the white and reddish-tan sand, with little or no textural change, suggesting that the entire sand originally was white in color. The present reddish-tan color could be due to infiltration of rainwater carrying pigmentation from overlying leaf litter or soil. The dark brown layer immediately below the white sand might have developed from an older accumulation of leaf litter or soil before the overlying layer was deposited. These observations suggest two distinct waves separated in time by years. The colors mentioned are similar to those in Figure 7.

the unique character and morphology of the deposits. Similar deposits are found at two distant rocky headlands, one about 60 $\mathrm{km}$ to the north and the other located about $190 \mathrm{~km}$ to the south of Akumal; a total of $250 \mathrm{~km}$ apart.

\section{Berm Characteristics and Stratigraphy}

The coastal berm comprises two sedimentary facies: a boulder-paved gravel berm across headlands and a beachsand-and-small-boulder berm across bays. Together, these facies define the geographic pattern of the berm, which tracks the shapes of present day headlands, bays and transcoastal 


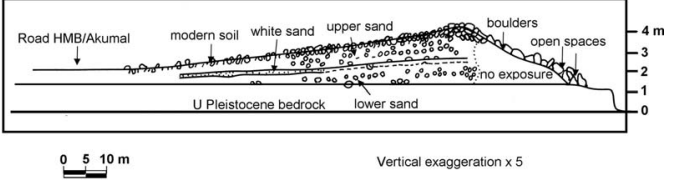

Figure 9. Cross section through the headland berm at Mi Casa del Mar, Akumal. Vertical scale is $5 \times$. The cross section attempts to integrate relationships discussed in the text and in the photographs in Figures 7A and 7B and in Figure 8. The cover of large boulders on the outside of the berm could have been a late event.

channels. Large, angular boulders pave the seaward face of the berm along the coastal headlands, spectacularly so on the Akumal headland (Figures 2 and 3) and at Punta Soliman, where hundreds of strongly imbricated boulders $1 \mathrm{~m}$ in length pave the berm. At the site of Mi Casa del Mar Condominiums at Akumal (locality A on Figure 6), boulders also pave the landward side of the berm for $70 \mathrm{~m}$ on a $120-\mathrm{m}-$ wide, inland-sloping wedge of sediment (Figures 4 and 9). The wave, with its load of sediment, achieved a coastal runup of $4.5 \mathrm{~m}$ above present sea level and possibly $6 \mathrm{~m}$ when a sea level $1.5 \mathrm{~m}$ lower at 1500 years before present (YBP) is included. Berm deposits extend $150 \mathrm{~m}$ inland from the headland shore.

\section{Overview of the Trenches at Akumal}

Figure 4 shows the inland side of the berm at the construction site for Mi Casa del Mar Condominiums after vegetation had been removed. The photograph in Figure 7A shows the same site after excavation had opened a network of trenches. Broadly, the stratigraphy visible in Figure 7A consists of two main layers. A lower layer of coarse, unbedded, tan sand contains numerous small and large floating boulders, similar to a structureless sand attributed to tsunami shown in Bryant (2001, figure 3.8, p. 74). The upper layer consists of a basal zone of white sand overlain by reddish-brown gravel. Figure 7B shows that the gravel is composed of densely packed, angular clasts, most with pronounced tabular shapes and oriented subparallel to the surface of the berm. Figure 7B also shows that some cobbles have been fractured, forming a mosaic of fitted pieces, which suggests that the cobbles were emplaced with considerable force. Pebbles in the upper layer show a fabric similar to that in Bryant (2001, figure 3.6, p. 69), which he characterizes as a "dump" deposit and attributes to a tsunami. Loose pebbles and cobbles at the bottom of the trench convey a sense of clast textures and shapes. Gravel in both layers, as far as known, is composed of Pleistocene reef rock from the headland mixed with pieces of modern coral within a matrix of coarse sand. There is little or no fine sand, silt, or clay in either layer. Both layers are $>1 \mathrm{~m}$ thick near the top of the berm ridge and thin inland to $0 \mathrm{~m}$ at around $120 \mathrm{~m}$ from the berm face. The top gravel shows no discernable downslope gradation in grain size but does grade with depth from pebblerich at the top to sand with scattered small pebbles at the bottom (Figure 8). Any size gradation in the lower sand is not discernable in the photographs.

\section{Description of White Sand}

Near the berm crest, the upper and lower sands appear to be separated by a zone of white sand. Careful inspection of the white sand in Figure 8 reveals a clear gradation upward to tancolored sand with increased pebble content. A few angular pieces of coral and small pebbles can be seen within both the white and tan parts of the upper sand. At the very top, Figure 8 shows a thin cap of tabular cobbles beneath the surface cap of cobbles and boulders.

In contrast to the gradational boundary above, the contact between white sand and the lower tan sand is sharp, with no hint of gradation. Sand immediately below the contact has a dark cast at the top and contains scattered masses of black organic material at the contact, but similar material has not been found lower (Figure 8). The dark tan color immediately below the white sand grades to lighter tan below. All of these characteristics can be seen in Figures 7A and 7B and in Figure 8. Bryant's (2001, p. 74) figure 3.6, interpreted by him as a tsunami deposit, shows a ball of dark material similar to that in Figure 8 that appears to have been transported and deposited with the pebbles in the surrounding sand.

The white zone in the Akumal deposit can be followed around most of the trenches (Figure 7A). In places, the white color is absent or reduced to a line of pebbles. Figure $7 \mathrm{~B}$ shows a channel filled with white gravel grading to dark tan gravel above. Figure 7A shows several dark masses of organic material immediately below the white zone.

The gradational contact between the upper, pebbly, reddishtan sand and the white sand near the berm crest and the white gravel in Figure 7B suggests that the reddish brown color could be due to leaching of pigment from overlying soil or leaf litter that colored originally white sediments. This interpretation seems clear in Figure 8 and in the way the color change maintains its thickness across the top part of the gravel-filled channel in Figure 7B. A similar argument can be made for the origin of the darker color at the top the lower layer and its association with dark organic material. If correct, these relationships would indicate two waves separated by sufficient time to develop the necessary accumulation of leaf litter or development of soil on top on the lower layer. The boulder pavement on the Akumal berm might require a third wave, either immediately after the upper sand was deposited or possibly much later. We are uncomfortable with the three-wave hypothesis for reasons explained in the "Discussion" section.

\section{Other Berm Deposits}

Sediments exposed in a shallow excavation on the edge of the Yal $\mathrm{Ku}$ channel ( $\mathrm{F}$ in Figure 6) are identical to the crudely layered gravel in the upper layer at Mi Casa del Mar and suggest that the broad stratigraphic pattern observed there probably is continuous between the two sites.

Two outliers of berm-type deposits mentioned above are separated by around $250 \mathrm{~km}$. One of these is located at the lighthouse just north of Majagual on the south coast of the Méxican Yucatán Peninsula. This site lies $>190 \mathrm{~km}$ to the south of Akumal, far outside the area in Figure 1, but its location at the lighthouse at Majagual will guide any who want to visit the site. The lighthouse is built on a gravel berm, the seaward side of which is paved with large boulders. The berm 


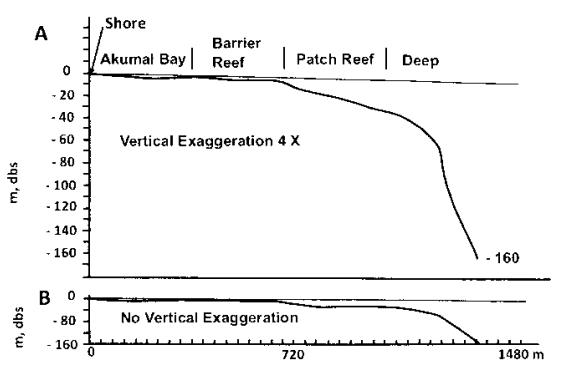

Figure 10. Bathymetric profile between the beach at Akumal Bay and 1300 $\mathrm{m}$ offshore. The gently sloping bottom seaward of the barrier reef zone is covered by a thin layer of coarse sand close to shore, a possible source of similar sand deposited in the berm.

rests on a Pleistocene headland composed of fossilized coral, as at Akumal. The second outlier is located about $60 \mathrm{~km}$ north of Akumal at Playa Secreto, $10 \mathrm{~km}$ south of Puerto Morelos (Figure 1). A small rocky point at Punta Secreto is approximately at sea level, exposes Pleistocene calcarenite containing scattered corals, and is overlain by a patchy cover of beach sand. A gravel berm is located 10-20 m inland from the shore and has an elevation of $4 \mathrm{~m}$. The gravel contains small, modern coral heads of Montestraea sp. Large imbricated blocks of Pleistocene limestone $(1 \times 0.3 \mathrm{~m})$ mixed with modern coral heads pave the seaward face of the berm (from notes of 3 June 1998). Assuming the two outliers are the same age as berm deposits on the rocky headlands at Akumal, they would imply that the wave(s) that deposited the Akumal berm, also affected at least $250 \mathrm{~km}$ of the Méxican Caribbean coast. Alternatively, the outliers could be of different ages and indicate waves that impacted the coast at different times.

\section{Beaches}

Bays between the rocky headlands on the Caribbean coast of the Yucatán Peninsula are lined by white, carbonate-sand beaches composed of comminuted shells and coral. At each end of the beach, the berm topography on the headland, with its pavement of boulders, turns into the bay, and the coarse, angular gravel of the berm becomes boulder-rich beach sediment (Figure 5), indicating that the berm facies on the headlands probably were deposited simultaneously with the beach facies. The boulder-rich berm in the bays has since been reworked by waves and mixed with modern beach sand.

Near the center of Half Moon Bay the berm is composed mostly of medium to coarse beach sand, with a few layers of fistsized cobbles. The base of the sand rests on top of peat described next.

\section{Peat}

During construction of Playa Caribe Condominiums on Half Moon Bay (locality C on Figure 6), excavations uncovered mangrove peat directly beneath the most landward and thickest part of the beach. Mangrove peat inland from the beach on Figure 6 can be traced continuously to peat beneath beach sand. Woody peat particles also were observed swirling in the surf along the shore. Investigation showed peat beneath a few centimeters of sand in the surf zone. Mangrove peat, therefore, appears to be continuous between the modern mangrove and the present surf zone and possibly beyond, indicating that the eastern edge of the mangrove lay seaward of the modern beach at the time the berm was deposited and that sea level, therefore, was lower than at present. Samples of peat from beneath the surf zone were collected for carbon dating in front of La Joya Condominiums (locality D on Figure 6).

\section{Pumice}

Rounded pebbles of light-gray pumice may be found in beach sand at a number of bays along the coast, including Akumal Bay. At Akumal, pumice is abundant near the south end of Akumal Bay, especially in a high, steep beach face there. No pumice has been found in berm deposits on the headlands and appears to be absent in beach sand presently being worked by waves in Half Moon Bay, in Akumal Bay, and at Playa del Carmen. Pumice found south of the ferry dock at Playa del Carmen was dug from a 30-cm scarp in the beach sand located 1 $\mathrm{km}$ south of the dock and 20-30 m inland from the modern shore. Rounded ball-shaped pumice $10-15 \mathrm{~cm}$ in diameter also was seen on the beach at Playa Secreto. Pumice rafts have been described from Krakatau, which erupted in Indonesia in 1883 (Carey et al., 2001) and other places in the Pacific Basin (Bryant, 2001, p. 14), where they are associated with eruptions of acidic volcanos.

Pumice in modern Méxican beach sand may be entirely unrelated to the deposits discussed here but do suggest a source from an acidic volcano somewhere in the Caribbean Basin. Although such eruptions may initiate tsunami (Bryant, 2001), at present, the pumice on the Yucatán shores can only be said to have arrived on this coast after the berm was emplaced.

\section{Local Bathymetry near Akumal}

The bays, headlands, and reefs of the high coast are very shallow features compared with the topography of the sea floor offshore. The cover of Holocene sand on the shallow platform appears to be very thin. Coarse sand that covers the sea floor in front of the headland at Akumal is only $10-15 \mathrm{~cm}$ thick at $10 \mathrm{~m}$ depth and overlies fresh-looking gray limestone. The thin cover of sand close to the headland has a texture and fabric similar to that in the white sand found in the headland berm.

Topography east of the present coast deepens seaward in a series of steps. The large step $1200 \mathrm{~m}$ offshore was mapped in the late 1990s by Dr. Andrew Fischer and his students using a Garmin sonar depth finder/GPS provided by Centro Ecológico Akumal and Surfer 8 contouring software contributed by Golden Software (2002). The sea floor outside Akumal Bay slopes gently seaward from a depth of $10 \mathrm{~m}$ in front of the modern reef to a depth of approximately $30 \mathrm{~m}$ at $1200 \mathrm{~m}$ offshore, where it drops abruptly to $160 \mathrm{~m}$ (Figure 10); this is the approximate elevation of the sea level low stand during the Wisconsin glacial period. The east coast of Cozumel, $40 \mathrm{~km}$ to the east, marks the position of a submarine scarp that drops to $1000 \mathrm{~m}$ (Ness et al., 1991).

\section{Age of the Berm}

Age constraints for the berm and the wave(s) that produced it are threefold.

First, Maya constructions on top of the headland berm at Xcaret and at Calica, between Playa del Carmen and Paamul 
Table 1. Center for Accelerator Mass Spectrometry (CAMS) ${ }^{14}$ C age data for peat samples from the surf zone at Half Moon Bay, Akumal, Mexico. Values in \%o.

\begin{tabular}{llllrr}
\hline \hline CAMS No. & \multicolumn{1}{c}{ Sample Name } & $\delta^{13} \mathrm{C}$ & Fraction Modern & $\mathrm{D}^{14} \mathrm{C}$ & ${ }^{14} \mathrm{C}$ Age \\
\hline 35503 & Akumal Peat Bottom & -25 & $0.8194 \pm 0.0040$ & $-180.6 \pm 4.0$ & $1600 \pm 40$ \\
35504 & Akumal Peat Top & -25 & $0.8203 \pm 0.0054$ & $-179.7 \pm 5.4$ & $1590 \pm 60$ \\
\hline
\end{tabular}

$\delta^{13} \mathrm{C}$ values are the assumed values according to Stuiver and Polach (1977) when given without decimal places. Values measured for the material itself are given with a single decimal place.

The quoted age is in radiocarbon years using the Libby half life of 5568 years and following the conventions of Stuiver and Polach (1977).

Radiocarbon concentration is given as the fraction Modern, $\mathrm{D}^{14} \mathrm{C}$, and conventional radiocarbon age.

Sample preparation backgrounds have been subtracted, based on measurements of samples of ${ }^{14} \mathrm{C}$-free coal.

(Figure 1), indicate that the berm was deposited before construction of the buildings, which had to have taken place during the late postclassic period of Maya history, between $\mathrm{AD}$ 1200 and $\mathrm{AD}$ 1517, the latter date being when the Spanish arrived (Sabloff, 1989).

Second, the observation that the berm tracks modern coastal geography indicates that the coast was in its present form and the sea was close to its present level when the berm was emplaced. According to the curves of Milliken, Anderson, and Rodriguez (2008), sea level on the northern Gulf of Mexico was within $2 \mathrm{~m}$ of modern levels at around $4000 \mathrm{YBP}$. The curve of Toscano and Macintyre (2003) for the Caribbean is in close agreement. Indications of a sea level above present within the last 4000 years, such as eroded notches, have been proposed by Morton, Paine, and Blum (2000). Milliken, Anderson, and Rodriguez (2008) interpret their data from the central Gulf coast to indicate that such a rise would have to have been brief and $<2 \mathrm{~m}$ in height.
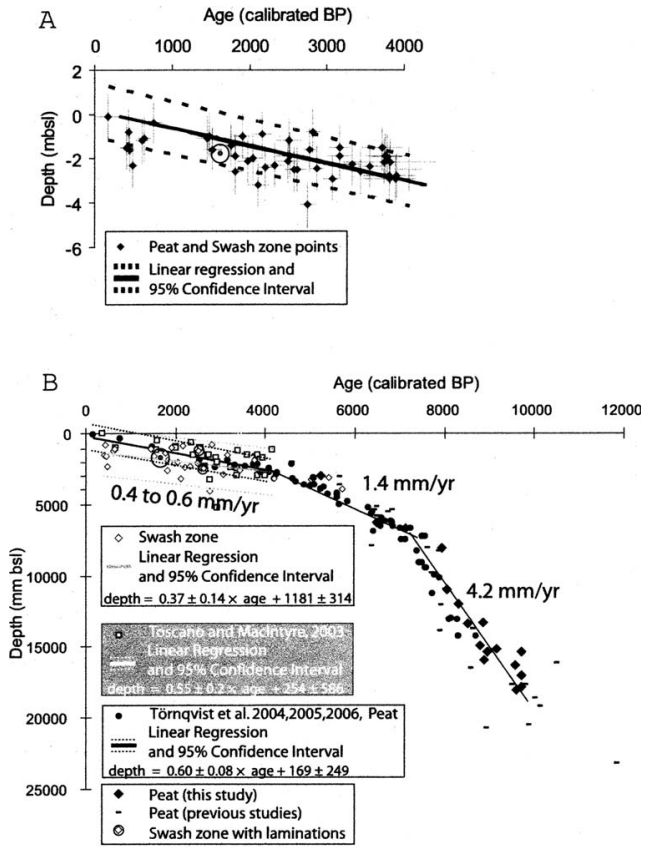

Figure 11. Two ${ }^{14} \mathrm{C}$ dates from peat collected in the swash zone at Half Moon Bay are plotted on the sea level curve of Milliken, Anderson, and Rodriguez (2008). Data reported in this paper are indicated by the point within a large circle at $1500 \mathrm{YBP}$ and $1.5 \mathrm{~m}$ depth, comfortably within the $95 \%$ confidence level indicated by the dashed lines. Figure after Milliken, Anderson, and Rodriguez (2008).
Third, samples of peat collected for radiocarbon dating from beneath the surf zone in front of La Joya Condominiums on Half Moon Bay yielded the ${ }^{14} \mathrm{C}$ ages shown in Table 1 . Twosigma calibrated ages for two samples (1390-1567 and 13481613 cal YBP; Stuiver, Reimer, and Reimer, 2005) are plotted as a single point enclosed by a large circle on the sea level curve of Milliken, Anderson, and Rodriguez (2008) in Figure 11 and fall within the indicated $95 \%$ confidence interval for the uppermost segment of the curve. Assuming the midpoint of the two ranges represents the best estimate of age, the peat was deposited at about $\mathrm{AD} 470$, or about 1500 YBP.

Radiocarbon dates reported by Ward $(1985$, p. 48) for a sample taken from the bottom of a 1.5-m core collected at Nichupte Lagoon near Cancun were interpreted by Ward as having been deposited at sea level throughout the interval represented by the core and, therefore, reflect a steady sea level rise of $1 \mathrm{~mm} / \mathrm{y}$ since $1500 \mathrm{YBP}$, a bit faster than the rate indicated by the slope of the curve of Milliken, Anderson, and Rodrigues (2008).

These ages satisfy constraints posed by the two Maya buildings on the berm, and the recent age required by conformity of the berm trace to the shape of the modern coastline.

\section{DISCUSSION}

Discussion of the geographic pattern of the berm along the coast relies on the idea that the headland berm and the beach berm in the bays are parts of a single continuous feature. There is no reason to assume that the waves(s) did not deposit sediments in the low areas occupied by modern bays. In fact, the continuation of berm sediments and relief along both sides of bays, and especially along transcoastal channels, as at Yal $\mathrm{Ku}$ Lagoon, demonstrates that the wave moved $400 \mathrm{~m}$ inland along the channel while lifting and depositing locally derived sediment and boulders along the sides. It is reasonable to infer, therefore, that the wave(s) also deposited a precursor to the present sand berm along the bays and that deposition near the bay center would fall at around $400 \mathrm{~m}$ inland. This conclusion does not mean, however, that the sediment composition in the bays was the same as on the headlands. A wave entering a bay would not cross a headland and would have no known source for large boulders and gravel. The photograph in Figure 5 (point B on Figure 6) shows part of an excavation that was opened for construction of Playa Blanca Condominiums. It is about $1.7 \mathrm{~m}$ high and about $100 \mathrm{~m}$ in length (the photograph shows only a few meters) and exposes a large volume of weakly bedded, subangular cobbles and boulders composed of creamcolored coral mixed and interbedded with beach sand. A modern soil at the top precludes deposition by recent storms. 
In contrast, the headland berm tapers inland and disappears within $150 \mathrm{~m}$ of the shore. Across bays, the beach facies record inundation of $400 \mathrm{~m}$ at the center (Figure 6), and the sediment wedge tapers seaward due to reworking by waves and the preexiting topography of the bay floor. Where the wave impacting the headland was unobstructed by topography along the transcoastal channel connecting Yal Ku Lagoon with the sea, berm deposits track both sides of the channel and end at $400 \mathrm{~m}$ inland, as in the bays, It appears that $400 \mathrm{~m}$ was the inland limit for unobstructed wave energy. If the same energy was expended on the headland within $150 \mathrm{~m}$ of the shore (Figures 6 and 9), the wave striking the headland expended $100 \%$ of its total energy in $<40 \%$ of the distance for the same energy expended in bays and channels over a distance of $400 \mathrm{~m}$.

\section{Backflow of Wave}

The photograph in Figure 5 is adjacent to a 200-m-wide gap in the beach berm at Half Moon Bay that requires explanation. We suggest that the gap could be the location of a channel that was eroded by water returning to the sea after the wave(s) had deposited the headland berm. Being unable to flow back uphill across the berm, flow would have moved laterally behind the coast and returned to the sea through the first low point available. The arrow near locality B on Figure 6 suggests one possible return path through the gap in the beach berm. A second channel on Akumal Bay, also marked by an arrow, is another possible return route.

\section{Paleotsunami vs. Cyclonic Storms}

Deposits from paleotsunami are difficult to separate from deposits of large cyclonic storms (Engel and Bruckner, 2011; Scheffers, 2002, 2004). The papers by Scheffers (2002, 2004) and Scheffers and Kelletat (2006) present a critique of arguments concerning the origin of boulder deposits that concludes with the observation that only the rarest of storm waves can move 1000 -ton boulders $10 \mathrm{~m}$ or more above sea level and 20-30 m inland, like those described by Hearty (1997). They also question whether storms can produce the imbrication of large boulders. Engel and Brückner (2011), on the other hand, present a table of 14 tsunami "signature types" that have been proposed in the literature along with studies supporting and opposing each type. The divergence of opinion, capably argued on both sides, casts doubt on the use of signature types to define tsunami at the present state of knowledge. Nevertheless, Felton (2002), in her study of gravels on rocky coasts in Hawaii, and Bahlburg and Weiss (2007), in their study of sediments deposited by the Indian Ocean tsunami of December 2004, plus the review of Engel and Brückner (2011), hold out hope that further research might eventually lead to a diagnostic "tsunami facies."

All recorded and verified Caribbean tsunami and all recent Caribbean earthquakes (Figure 12) have taken place within the central and eastern portions of the Caribbean Basin (i.e., on the Caribbean Plate). The western Caribbean Basin, including western Cuba, Yucatán, and the Gulf of México, are on the North American Plate and are seismically quiet. Although no observed Holocene tsunami have been reported in the western Caribbean, hurricanes are another matter. A plot by the National Oceanic and Atmospheric Administration (NOAA) of all historic hurricanes in the Atlantic Basin over the past 150 years is shown in Figure 13. The Yucatán Peninsula clearly sits in the heart of the Atlantic/Caribbean hurricane belt and experiences hurricanes or tropical storms almost every year. Not all are megastorms, and not all areas are hit each year, but the frequency has been high. This study was initiated by the observation of large boulders that pave the seaward and inland faces of a coast-parallel berm. Without doubt, the boulders that pave this solitary berm could have been deposited by one or more tsunami. We are doubtful that they were deposited by a hurricane, or several hurricanes, for the following reasons.

Reports of tsunami in the Caribbean Basin are few compared with hurricanes. Only 37 historical tsunami, verified by contemporary witnesses, are listed by Lander, Whiteside, and Lockridge (2002) for the period 1492-2010, and all but seven of those were in the Lesser Antilles, including those cited by Engel and Brückner (2011), Morton et al. (2008), Scheffers (2002, 2004), and Scheffers and Kelletat (2006). The oldest verified Caribbean tsunami struck Jamaica in AD 1692 (Lander, Whiteside, and Lockridge, 2002), and the most recent struck Haiti in $\mathrm{AD} 2010$, following the 2010 earthquake (Lovett, 2010).

Coastal deposits described in this paper indicate that up to three large waves might have struck the Caribbean coast of the Yucatán Peninsula at around 1500 YBP, after the coast had assumed its modern form. These waves could have been part of a single tsunami wave, a tsunami wave train, multiple tsunami separated in time, or one or more hurricanes. Morton et al. (2008) suggest that most berms are built incrementally by many storms over a few centuries or more, with an occasional tsunami in the mix.

Hundreds of hurricanes have crossed the Yucatán Peninsula in the $150+$ years since 1850, as shown by the plot in Figure 13. If the intense bombardment of the Yucatán by hurricanes over the last 150 years resembles the hurricane history of the past 1500 years, there would have been ample opportunity to build many berms in the manner proposed by Morton et al. (2008). Several of the tsunami-associated features listed by Bryant (2001) and by Engel and Bruckner (2011) fit the deposits described in this paper, including deposits above the reach of normal storm waves, a landward-tapering berm of mostly unbedded "dump" deposits with boulders suspended in sand, and imbricated boulder stacks.

Multiple berms above the reach of normal waves in $\mathrm{NE}$ Australia have been described as the observed result of super cyclones (Nott and Hayne, 2001), which are defined as storms with central pressures less than around 920 hectopascal $(\mathrm{hPa})$, where $1 \mathrm{hPa}=1$ millibar (mb). Super-cyclone berms from a single storm have been observed to reach $6 \mathrm{~m}$ in height and 18 $\mathrm{km}$ in length (Nott and Hayne, 2001). Nott and Hayne (2001) also describe several berms built by a single storm. These berms are composed of well-sorted and rounded cobble beach shingle and detrital corals and shells arranged in bands several meters high. The Yucatán deposits described above do not resemble these super-cyclone deposits in any way.

A comparable Yucatán storm that meets the super-cyclone definition is hurricane Gilbert, which had a central pressure of $888 \mathrm{mb}$ (NOAA-NWS, 2010). Gilbert, one of the most powerful storms on record, struck the Yucatán shore at Cancun and then followed a well-traveled path across the northern tip of the 


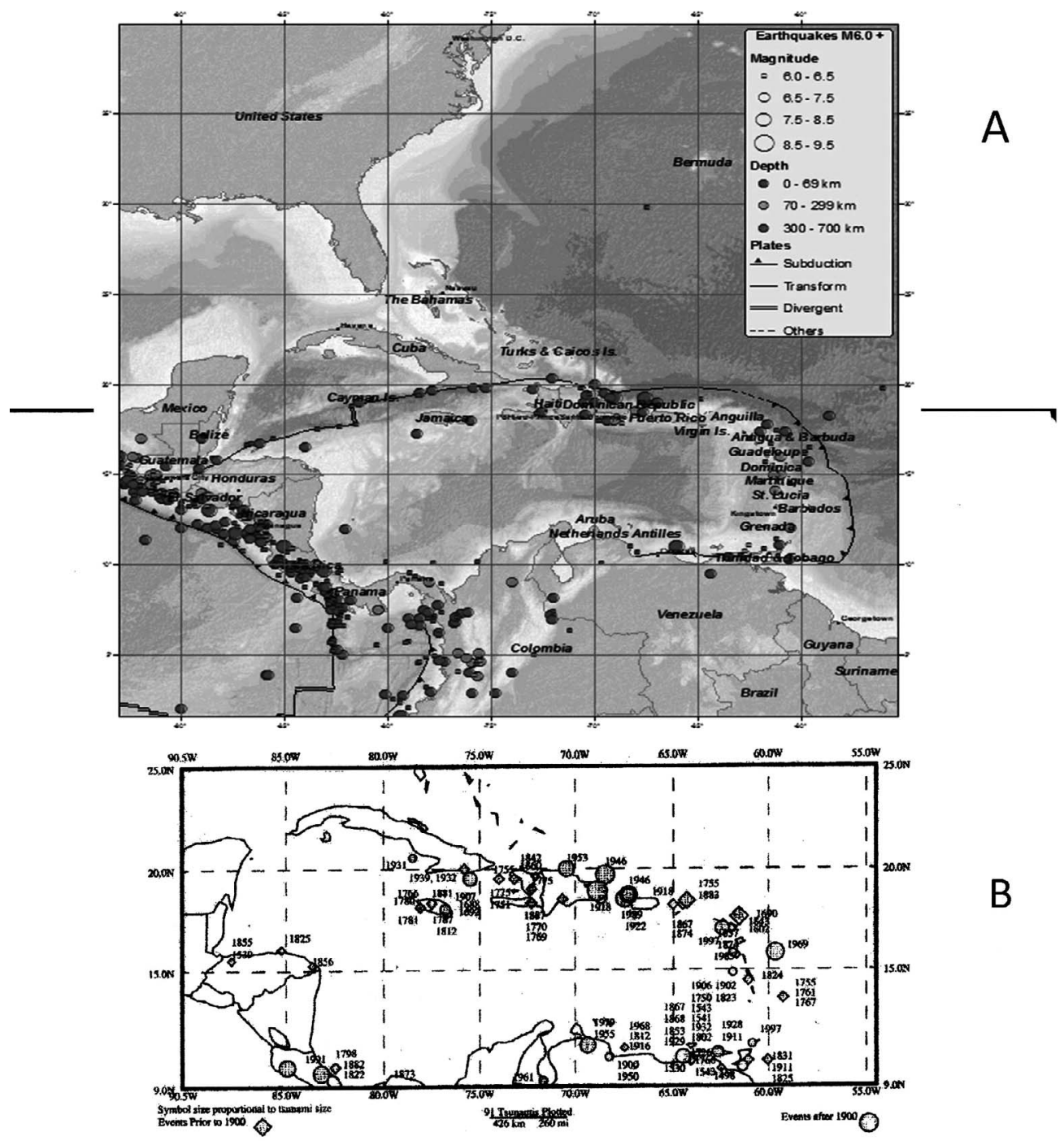

Figure 12. Historical tsunami compared with historical earthquakes in the Caribbean Basin. (A) Historical earthquakes plotted as circles, with diameters indicating earthquake magnitude. Epicenters for the vast majority of historical earthquakes are in the Lesser Antilles and near Puerto Rico. Fewer earthquake epicenters are strung out westward along the Cayman Trench. Farther west, only a few earthquakes follow the trench into the large recess in the coast between Honduras and Belize. No earthquakes are plotted north of the Cayman Trench. (B) Historical hurricanes in the Caribbean Basin. These follow the same pattern as the pattern of earthquakes. Only a fraction of earthquakes initiate tsunami, but those that do are in the Caribbean Plate. The Yucatán Peninsula and western Cuba are on the North American Plate and are seismically quiet. Panel A from U.S. Geological Survey. Panel B from Lander, Whiteside, and Lockridge (2002).

peninsula (Figure 14). The Pacific cyclone described by Nott and Hayne (2001) and hurricane Gilbert are directly comparable in intensity and size, but, unlike the Pacific storm, Gilbert failed to create either the berm features described in this paper or the shingle berm found in NE Australia. The fact that the geological settings are so different in the areas where each storm reached land might account for most differences in the type of deposits, or, in the case of Gilbert, the lack of them. The eye of Gilbert came ashore on the low coast south of Cancun then moved west along the north Yucatán coast (Figure 14). Coastal areas to the south of the counterclockwise-rotating cyclonic circulation would have to receive winds off the land, reducing wind strength and damage, and certainly not depositing much in the way of sediment, but remaining very powerful nonetheless. Several less powerful hurricanes hit the Yucatán in the 20th and early 21st centuries, but none, before or after Gilbert, have generated any recognized berm deposits on the Yucatán Peninsula. With 1500 years of these storms, it seems likely that more than one has passed over the high coast between Tankah and Playa del Carmen. If so, why is there only one solitary berm? The berm described in this paper is the only Holocene deposit above wave level we have found on the Caribbean coast. It appears that neither the low-lying mangrove coast of the Méxican Caribbean nor the rocky headlands favor cyclonic deposits like those reported by Nott and Hayne (2001) in NE Australia. 


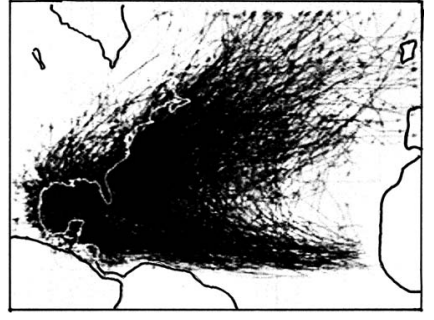

Figure 13. Atlantic hurricanes and storms 1850-2000. The Yucatán Peninsula lies in the heart of the hurricane pathway, as does Florida. Map from National Weather Service (NWS).

An attractive alternative to hurricanes or tsunami initiated by earthquakes is suggested by the work of Grindlay, Hearne, and Mann (2005); Grindlay, Mann, and Dolan (1997); and ten Brink et al. (2006), who reported the presence of very large slump features in $3 \mathrm{~km}$ of water in the Puerto Rico trench and of cuspate scars on the shelf nearby. They and Schwab et al. (1991) compared these slumps to the Storegga slump off Norway, dated 8000 years ago (Jansen et al., 1987), that was the source of a 25- to 30-m-high tsunami that struck Scotland. The ages of the Puerto Rico slumps are so far undetermined, but the reported slump scars involve Pleistocene strata (Grindlay, Hearne, and Mann, 2005).

The character of the Caribbean coast of the Yucatán Peninsula, with its locally unique coastal area of headlands and bays bordered north and south by extensive mangrove, suggests a possible test of the tsunami (of whatever origin) $v s$. hurricane hypotheses for the Yucatán deposits. Atwater and Moore, (1992) and Hemphill-Haley (1995) report foraminiferabearing sand layers found within coastal marshes in southern Washington State that have been dated and correlated with tsunami at 1000 and $300 \mathrm{YBP}$, respectively. We suggest that if cores taken from sites in the coastal mangroves of the Yucatán were to encounter similar sands, and if dating of the enclosing organic-rich beds support a temporal correlation with the berm, the case for a tsunamigenic origin of the coastal berm and boulder deposits would become very strong.

\section{CONCLUSIONS}

Deposits that stretch for $50 \mathrm{~km}$ across the rocky portion of the Méxican Caribbean coast are testimony to the power of the wave(s) that struck the Yucatán around 1500 YBP. The fact that only one deposit of this type is known from the Yucatán coast is puzzling if the deposits described were generated by hurricanes, which have impacted the Yucatán coast with great frequency. Tsunami, on the other hand, appear to be rare in the western Caribbean, so it makes sense that their deposits also would be rare. At present, the only unequivocal way to determine the origin of such deposits is by direct observation, something not possible for paleotsunami. We have proposed a program that might settle the question of origin of the Yucatán berm and boulders.

Until then, we conclude that the Yucatán deposits more resemble the work of observed tsunami than of observed hurricanes.

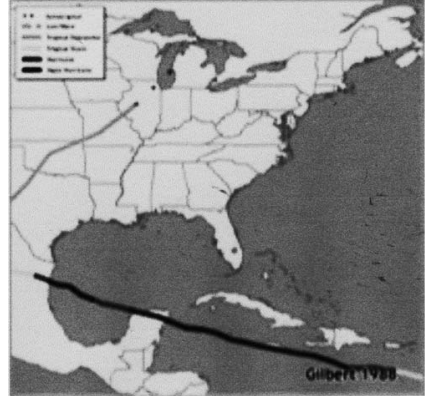

Figure 14. Track of hurricane Gilbert, 1988. Hurricane Gilbert is included in the dark mass on Figure 13 but is shown separately in this figure as an aid to discussion in the text. Map from NWS.

The State of Quintana Roo and its principal population centers in the north, which include Cancun, Playa del Carmen, and Tulum, did not exist 1500 YBP when an extreme wave, likely a tsunami, struck the Yucatán coast. The coast was thinly populated at the time, but recent growth has been enormous. During the early 1980s development was still confined mostly to Cancun, a time when Playa del Carmen had a population of only 300 people, compared with the present population of 150,000 to 200,000 people. By 2000 , the coastal region had a total population of 493,000 people, and by 2010 , the latest census available (INEGI, 2010) had grown to 1.36 million. Extensive damage and loss of life would be expected should a similar wave strike the present coast. However, considering that we know of only one possible paleotsunami on the Yucatán coast in the past 1500 years, the modern Yucatán coast faces more frequent dangers from extreme cyclonic storms in this age of a warming planet than from a possible tsunami every few thousand years.

\section{ACKNOWLEDGMENTS}

Work in the field by Shaw was supported by Centro Ecológico Akumal. Benson acknowledges support from the U.S. Geological Survey. Radiocarbon dates were run by Lawrence Livermore Center for Accelerator Mass Spectrometry. We acknowledge grants from the PADI Foundation and the contribution of software from Golden Software LLC. We are grateful to two anonymous reviewers for their insightful suggestions and patient prodding, which resulted in significant improvements in the presentation of data and the framing of conclusions.

\section{LITERATURE CITED}

Atwater, B.F. and Moore, A.L., 1992. A tsunami about 1000 years ago in Puget Sound, Washington. Science, 258(5088), 1614-1617.

Bahlburg, H. and Weiss, R., 2007. Sedimentology of the December 26, 2004, Sumatra tsunami deposits in eastern India (Tamil Nadu) and Kenya. International Journal of Earth Sciences, 96(6), 1195-1209.

Bryant, E., 2001. Tsunami: The Underrated Hazard. Cambridge, U.K.: Cambridge University Press, 320p.

Carey, S.; Morelli, D.; Sigurdsson, H., and Bronto, S., 2001. Tsunami deposits from major explosive eruptions: An example from the 1883 eruption of Krakatau. Geology, 29(4), 347-350.

Engel, M. and Brückner, H., 2011. The identification of paleo-tsunami deposits-A major challenge in coastal sedimentary research. In: 
Karius, V.; Hadler, H.; Deicke, M.; von Eynatten, H.; Brückner, H., and Vött, A. (eds.), Dynamische Kusten-Prozesse, Zusammenhänge und Auswirkungen. Coastline Reports 17. Rostock, Germany: The Coastal Union Germany, pp. 65-80.

Felton, E.A., 2002. Sedimentology of rocky shorelines: 1. A review of the problem with analytical methods and insights gained from the Hulope gravel and the modern rocky shoreline of Lanai, Hawaii. Sedimentary Geology, 152(3-4), 221-245.

Golden Software, 2002. Surfer 8. Golden, Colorado: Golden Software LLC.

Grindlay, N.; Mann, P., and Dolan, J., 1997. Researchers investigate submarine faults north of Puerto Rico. EOS, Transactions, American Geophysical Union, 78(38), 404.

Grindlay, N.; Hearne, M., and Mann, P., 2005. High risk of tsunami in the northern Caribbean. EOS, Transactions, American Geophysical Union, 86(12), 121-132.

Hearty, P.J. 1997. Boulder Deposits and large waves during the Last Interglaciation on North Eleuthera Island, Bahamas. Quaternary Research, 48(3), 326-328.

Hemphill-Haley, E., 1995. Diatom evidence for earthquake-induced subsidence and tsunami 300 years ago in southern coastal Washington. Bulletin of the Geological Society of America, 107(3) 367-368.

INEGI, 2010. Instituto Nacional de Estadística, Geografía y Información: Censo de Población y Vivienda 2010. http://www.inegi. org.mx.

Jansen, E.; Befring, S.; Bugge, T.; Eidvin, T.; Holtedahl, H., and Sejrup, H.P., 1987. Large submarine slides on the Norwegian continental margin: Sediments, transport and timing.Marine Geology, 78(1-2), 77-107.

Jones, B. and Hunter, I.G., 1992. Very large boulders on the coast of Grand Cayman: The effects of giant waves on rocky coastlines. Journal of Coastal Research, 8(4), 783-789.

Lander, J.F.; Whiteside, L.S., and Lockridge, P.A., 2002. A brief history of tsunamis in the Caribbean. Science of Tsunami Hazards, 20(1), 57-94.

Lovett, R.H., 2010, Haiti earthquake produced deadly tsunami Nature, 25 February 2010. doi:10.1038/news.2010.93

Milliken, K.T.; Anderson, J.B., and Rodriguez, A.B., 2008. A new composite Holocene sea-level curve for the northern Gulf of Mexico. Geological Society of America Special Papers, 443, 1-11.

Morton, R.A.; Paine, J.G., and Blum, M.D., 2000. Responses of stable bay-margin and barrier-island systems to Holocene sea-level high stands, western Gulf of Mexico. Journal of Sedimentary Research, 70(3), 478-490.

Morton, R.A.; Richmond, B.M.; Jaffe, B.E., and Gelfenbaum, G., 2008. Coarse-clast ridge complexes of the Caribbean: A preliminary basis for distinguishing tsunami and storm wave origins. Journal of Sedimentary Research, 78(9), 624-637.

Ness, G.E.; Dauphin, J.P.; Garcia-Abdesiem, J., and AlvaradoOmana, 1991. Bathymetry and Gravity and Magnetic Anomalies of the Yucatán Peninsula and Adjacent Areas. Boulder, Colorado:
The Geological Society of America, Map and Chart Series MCHO73, scale 1:1,565,000, 3 sheets.

NOAA-NWS (National Oceanic and Atmospheric AdministrationNational Weather Service), 2010. Notable Tropical Cyclones. http:// www.srh.noaa.gov/srh/jetstream/tropics/tc_notable.htm.

Nott, J. and Hayne, M., 2001. High frequency of 'super-cyclones' along the Great Barrier Reef over the past 5000 years. Nature, 413(4), 508-511.

Sabloff, Jeremy A.,1989. The New Archeology and the Ancient Maya. New York: Scientific American Library, 194p.

Scheffers, A., 2002. Paleo-tsunamis in the Caribbean: Field evidence and datings from Aruba, Curacao and Bonaire, Volume 33. Essen, Germany: Essener Geographische Arbeiten, 181p.

Scheffers, A., 2004. Tsunami imprints of the leeward Netherlands Antilles (Aruba, Curacao, Bonaire) and their relation to other coastal problems. Quaternary International, 120(1),163-172.

Scheffers, A. and Kelletat, D., 2006. New evidence and datings of Holocene paleo-tsunami events in the Caribbean (Barbados, St. Martin and Anguilla). In: Mercado, A. and Irizarry, P.L. (eds.), Caribbean Tsunami Hazards. Proceedings of the NSF Caribbean Tsunami Workshop. San Juan, Puerto Rico: U.S. National Science Foundation, pp. 178-204.

Schwab, W.C.; Danforth, W.W.; Scanlon, K.M., and Masson, D.G., 1991. A giant submarine slope failure along the northern insular slope of Puerto Rico. Marine Geology, 96(3-4), 237-246.

Shaw, C E., 1996. Coastal geomorphology of the Méxican Caribbean: A legacy from the Pleistocene. Geological Society of America Abstracts with Programs, 28(7), A301.

Shaw, C.E. Late Pleistocene bays and reefs: Ancestors to the modern Caribbean coast, Yucatán Península, México. Journal of Coastal Research, in press. doi:10.2112/JCOASTRES-D-14-00083.1

Stuiver, M. and Polach, H.A., 1977. Discussion; reporting of C-14 data. Radiocarbon, 19(3), 355-363.

Stuiver, M.; Reimer, P.J., and Reimer, R.W., 2005. CALIB 6.01. http:// calib.qub.ac.uk/calib/ (superseded by CALIB 7.0).

Taggart, B.E.; Lundberg, J.; Carew, J.L., and Mylroie, J.E., 1993. Holocene reef rock boulders on Isla de Mona, Puerto Rico, transported by a hurricane or seismic sea wave. Geological Society of America Abstracts with Programs, 25(6), A61.

ten Brink, U.S.: Geist, E.L.; Lynett, P., and Andrews, B., 2006. Submarine slides north of Puerto Rico and their tsunami potential In: Mercado, A. and Liu, P. (eds.), Caribbean Tsunami Hazard. Singapore: World Scientific Publishers, pp. 67-90.

Toscano, M.A. and Macintyre, I.G., 2003. Corrected western Atlantic sea-level curve for the last 11,000 years based on calibrated ${ }^{14} \mathrm{C}$ dates from Acropora palmata framework and intertidal mangrove peat. Coral Reefs, 22(3), 257-270.

Ward, W.C., 1985. Quaternary geology of the northeastern Yucatan Peninsula. In: Ward, W.C.; Weidie, A.E., and Back, W. (eds.), Geology and Hydrogeology of the Yucatan and Quaternary Geology of the Northeastern Yucatán Peninsula. New Orleans, Louisiana: New Orleans Geological Society, 160p. 